\title{
Derivatives and Systemic Risk: What Role Can the Bankruptcy Code Play?
}

\author{
Franklin R. Edwards and Edward R. Morrison ${ }^{\dagger}$ \\ Columbia University
}

In Fall 1998 the Federal Reserve Bank ("Fed") arranged a bailout of the massive hedge fund, Long Term Capital Management (LTCM), which faced the prospect of immediate liquidation if it filed a petition under Chapter 11 of the Bankruptcy Code. Although the Code generally prevents creditors from seizing assets of firm in bankruptcy (also called the "automatic stay"), counterparties to derivative contracts receive special treatment under the Code and are free to terminate contracts and seize collateral to the extent they are owed money. Defending the Fed's decision to assist LTCM, Alan Greenspan explained:

[T] he act of unwinding LTCM's portfolio in a forced liquidation [precipitated by LTCM's derivatives counterparties] would not only have a significant distorting impact on market prices but also in the process could produce large losses, or worse, for a number of creditors and counterparties, and for other markets participants who were not directly involved with LTCM ... . Had the failure of LTCM triggered the seizing up of markets, substantial damage could have been inflicted on many market participants ... and could have potentially impaired the economies of many nations, including our own."

The Fed believed that its intervention was necessary to avoid a systemic meltdown that might arise from LTCM's liquidation-a liquidation made possible by the Bankruptcy Code's special treatment of derivative contracts (see, e.g., Krimminger, 1999).

The irony here is that the Bankruptcy Code's special treatment of derivatives stems from a desire to avoid systemic risk. Thanks to an exemption from the Code's automatic stay-which bars all other creditors from terminating contracts with or seizing assets from a firm in bankruptcy-counterparties to derivatives contracts are free to terminate the contracts and then seize collateral to the extent that they are owed money. As reported in legislative history, Congress believed this exemption from the automatic stay was necessary to prevent the "insolvency of one commodity or security firm [from] spreading to other firms and possibly threatening the collapse of the affected market." ${ }^{2}$ In other words, Congress amended the Bankruptcy Code to prevent a systemic collapse that might arise if a derivatives counterparty were unable to liquidate its contracts with a bankrupt debtor immediately. But, as the LTCM experience demonstrates, permitting the immediate liquidation of a large financial institution counterparty such as LTCM can generate another form of systemic risk, namely the risk that a "run" by derivatives counterparties on the debtor will itself destabilize financial markets.

The Fed's intervention to aid LTCM, therefore, calls into question the policy rationale underlying the Bankruptcy Code's special treatment of derivatives. In this paper, we make the following claim: derivatives may deserve special treatment, but not for the reason commonly given. When systemic risk is a legitimate concern, the Code can do little to mitigate it, and may even make matters worse, especially in cases in which large financial institutions (such as LTCM) are involved. But if systemic risk is a red herring, is there any justification for treating derivatives contracts differently under the Bankruptcy Code? We think there is: that derivatives (and the associated cash collateral) are not firm-specific assets and therefore giving them special 
treatment will increase economic efficiency. But this view is admittely controversial because its acceptance implies that we should be willing to accept significant changes in other provisions of the Code: in particular, that other assets with similar characteristics (such as cash collateral) should be given the same special treatment.

We begin with a description of the Code's special treatment of derivatives contracts and the common justification given for it. We then challenge this conventional wisdom, arguing that the Code is a poor tool for reducing systemic risk. Indeed, as the case of LTCM illustrates, the Code may in fact exacerbate this risk. Our argument naturally raises the question whether there are alternative (efficiency-based) justifications for the special treatment given to derivatives contracts under the Bankruptcy Code. There are. Derivatives, like cash and other financial assets, are fungible and can be seized by creditors without endangering a firm's going-concern value $e x$ post. The efficiency benefits ex post are offset potentially by the ex ante costs of a rule favoring derivatives contracts, which encourages rent-seeking by creditors seeking to disguise loans as derivatives contracts. We doubt these ex ante costs are significant, but if we are wrong there is no principled reason for offering special treatment under the Bankruptcy Code to derivatives contracts.

\section{Derivatives contracts and the Bankruptcy Code}

When a firm files a bankruptcy petition, it immediately enjoys the benefit of the Bankruptcy Code's "automatic stay," which forbids any creditor from taking steps to collect debts, seize assets, or otherwise "exercise control over property" of the debtor firm. ${ }^{3}$ The automatic stay is a core element of any attempt to reorganize under the Code. By shielding the debtor's assets and preventing a race that rewards the first creditor to the courthouse, it avoids dismemberment of a firm with going-concern value and facilitates a collective proceeding in which the parties (debtor and creditors) can negotiate the terms under which the firm will continue as a going concern.

There are, however, many exceptions to the automatic stay. Some are intuitive. The stay, for example, does not extend to the government's police or regulatory power; a debtor cannot avoid criminal prosecution or the enforcement of environmental protection laws (unless, of course, the government is simply using its regulatory powers to collect debts). ${ }^{4}$ Along the same lines, a bankrupt educational institution cannot use the stay to prevent accrediting agencies, state licensing bodies, or the Secretary of Education from a reevaluation of the institution's quality and eligibility for funding. ${ }^{5}$ Here we see a Congressional judgment that the benefits of government regulation outweigh the costs to the debtor.

Other exceptions are less intuitive, especially those involving derivatives contracts, such as futures, forwards, repos, and swaps. When a firm enters bankruptcy, a counterparty typically may cancel and net various contracts (in-the-money contracts are netted against out-of-the money contracts) and then seize collateral to the extent that the troubled firm is a net obligor to the counterparty. (See Novikoff, 2002.) The special treatment of derivatives contracts is not new. When the Bankruptcy Code was enacted in 1978, it contained an exemption from the automatic stay for non-debtor brokers and forward merchants with respect to transactions involving margin payments or deposits received from a debtor under a commodities contract or a forward contract. ${ }^{6}$ Amendments to the Code in 1982, 1984, and 1990 expanded the exemption to include an array of financial transactions known as "derivatives securities" contracts, including forward 
contracts, commodity contracts, repos, and swaps. Counterparties to a derivatives securities contract may now terminate, modify, or liquidate assets of the debtor unhindered by the bankruptcy filing of a debtor, irrespective of whether the debtor is in default under the contract or agreement. Further, if counterparties hold other assets of the debtor they can typically effect an "offset" so long as they can enforce their rights against such assets without having to require the assistance of the debtor. Thus, in general, the rights of counterparties to derivatives transactions with respect to collateral and its liquidation are derived from the contract or agreement between the protected party and the debtor, as opposed to the bankruptcy code.

The exceptions are set to grow. Recently proposed legislation would, among other things, extend the bankruptcy stay exemption to a wide variety of equity and credit derivative transactions, and would further extend the rights of counterparties to enforce netting arrangements documented under ISDA Master Agreements. Specifically, it would extend closeout netting between swap agreements, on the one hand, and securities and forward contracts, on the other hand.

Why are derivatives contracts treated differently? If legislative history is to be credited, Congress reasoned that special treatment of derivatives was necessary to prevent the "insolvency of one commodity or security firm [from] spreading to other firms and possibly threatening the collapse of the affected market." It believed that "prompt liquidation of an insolvent's position is generally desirable to minimize the potentially massive losses and chain reaction of insolvencies that could occur if the market were to move sharply in the wrong direction." ${ }^{8}$ Congress, then, carved derivatives out of the scope of the automatic stay in order to reduce the likelihood of systemic risk, i.e., the possibility that insolvency of a party to a derivatives contract might expose a counterparty and that counterparty's counterparties to financial distress, which would destabilize financial markets.

Congress' concern with systemic risk has some basis, as Edwards (1995) explains. Fear that a counterparty insolvency could trigger a systemic meltdown in the OTC derivatives market stems partly from the fact that this market is dominated by a few large international banks and securities firms. The ten largest OTC derivatives dealers are counterparties to most of the derivatives transactions that take place, and seven U.S. banks hold over 95 percent of the U.S. banking system's notional derivatives exposure. ${ }^{9}$ This raises the possibility that a problem (such as insolvency) with a major derivatives dealer (i.e., a bank) could reverberate throughout the entire OTC derivatives market and cause financial distress far beyond derivatives markets.

While Congress' concern with systemic risk is understandable, its decision to address it through the Bankruptcy Code is deeply puzzling. At the very least, the language of the Code encompasses far too many transactions. Fear of systemic risk is warranted only in cases involving the insolvency of a major financial market participant, with whom other firms have entered derivatives contracts of massive value and volume. Yet the Code offers special treatment to derivatives no matter how large or small the counterparty. Thus, Congress' stated justification for the special treatment is incomplete, as it applies only to a fraction of all firms that enter into derivatives contracts.

At the same time, the Code's special treatment of derivatives contracts seems far too narrow. Fear of systemic risk justifies special treatment of a broad range of financial market transactions and participants, especially commercial banks. Indeed, fear of systemic risk originated in the banking sector, yet a bank cannot seize collateral whenever a debtor firm enters 
bankruptcy. Surely the risks that (apparently) motivated Congress' concern with derivatives are equally present when Enron, Worldcom, or United Airlines enters bankruptcy and, say, Chase Manhattan cannot collect its collateral (if it is a secured creditor) or expects only a few cents on the dollar (if it is unsecured) when the case concludes several years later. Yet nothing in the Code allows Chase to collect its collateral; nothing in the Code gives Chase or any other bank priority in payment when the case concludes. If systemic risk arises from transactions other than derivatives contracts, as it undoubtedly does, the Code's singular focus on derivatives contracts is puzzling.

It might be argued that this singular focus merely reflects the reality that commercial banks are subject to federal regulation while many derivatives counterparties are not. We do not fear a systemic collapse when Chase is unable to collect collateral from Enron because, thanks to capital requirements and other regulatory and supervisory constraints, Chase is unlikely to become financially distressed. This argument is troubling for two reasons. First, it seems odd to regulate some financial institutions directly (through capital requirements and the like) and others indirectly (through the Bankruptcy Code). The costs of direct regulation are borne by the institution itself; the costs of indirect regulation through the Code are borne by other creditors of a distressed firm. More importantly, it seems highly unlikely that the Code is an effective means of reducing systemic risk, as we show in the next section.

\section{Can the Bankruptcy Code reduce systemic risk?}

An answer to this question was suggested recently during the insolvency of Long-Term Capital Management(LTCM), a limited-partnership hedge fund founded in 1994. As Edwards (1999) discusses in greater detail, LTCM was highly leveraged and its operations in derivatives markets were broad and complex. While approximately 80 percent of LTCM's balance sheet positions were in seemingly safe treasury securities of major industrial countries, these were highly leveraged, at a ratio of 28-to-1 on-balance sheet as of August 31, 1998. And LTCM's offbalance sheet leverage was much greater. As of August 31, 1998, according to the President's Working Group on Financial Markets (1999), it held derivatives of about U.S. \$1.4 trillion in notional value on a capital base of approximately U.S. \$2.3 billion. LTCM held OTC swap contracts with a gross notional value in excess of $\$ 750$ billion, futures contracts with a gross notional value in excess of $\$ 500$ billion, and options and other derivatives with a notional value in excess of $\$ 150$ billion. It is estimated that LTCM had between 20,000 and 60,000 trades on its books, and that it had more than 75 counterparties to its derivatives contracts (see President's Working Group, 1999; GAO, 1999). ${ }^{10}$

After a series of large losses during 1998, by September 1998 LTCM had lost 50 percent of its equity and was in danger of not being able to meet the collateral obligations on its derivatives positions. Only the timely intervention of the Federal Reserve in organizing a creditor-bailout of LTCM in September 1998 prevented LTCM's default and collapse. A consortium of 14 banks and securities firms, the large creditors of LTCM, recapitalized LTCM to the tune of U.S. \$3.6 billion and took over the responsibility and obligations of resolving LTCM's financial difficulties. In essence, LTCM's large counterparties participated in a FederalReserve-organized out-of-court "work-out" for LTCM. Why was the intervention of the Federal Reserve necessary to do what one might expect could be done under standard bankruptcy law? 
In explaining the role of the Federal Reserve, William McDonough, the president of the Federal Reserve Bank of New York, stated that it was the Federal Reserve's judgment that the "abrupt and disorderly close-out of LTCM's positions would pose unacceptable risks to the American economy." ${ }^{11}$ According to McDonough, the rush of more than 75 counterparties to close out simultaneously hundreds of billions of dollars of derivatives contracts would have adversely affected many market participants with no connection to LTCM and would have resulted in tremendous uncertainty about how far prices might move. According to McDonough, "[u]nder these circumstances, there was a likelihood that a number of credit and interest rate markets would experience extreme price moves and possibly cease to function for a period of one or more days and maybe longer. This would have caused a vicious cycle: a loss of investor confidence, leading to further liquidations of positions, and so on."12 (At the time,LTCM's own estimate was that its largest 17 counterparties, in closing out their positions with LTCM, would have incurred losses in the aggregate of between U.S. \$3 billion and U.S. \$5 billion, with some individual firms losing as much as $\$ 500$ million. See Roth et al., 2001.)

At the root of the Federal Reserve's concern was the current U.S. insolvency law. ${ }^{13}$ As we have seen, current U.S. bankruptcy law exempts derivatives counterparties from the normal operation of the bankruptcy code: from the automatic stay provisions of the code. Thus, LTCM's derivatives counterparties could have terminated and liquidated their derivatives contracts with LTCM. Had this occurred, the effects would have been analogous to a "bank run" on LTCM's assets, possibly resulting in the systemic ramifications articulated by Federal Reserve officials. As Diamond and Rajan (2003) have argued, bank runs can cause or exacerbate liquidity shortages, resulting in systemic illiquidity with the potential to cause widespread contagion. A run by derivatives counterparties of the kind that could have occurred in the LTCM episode seems similar to a bank run in that it too could result in the immediate and widespread liquidation of assets at firesale prices.

In contrast, the financial instability that (Congress feared) might arise if derivatives transactions were not exempt from the automatic stay seems less systemic in nature and less likely to destabilize financial markets. Congress worried that losses by a derivatives counterparty could trigger "a chain reaction of insolvencies" by making it impossible for a counterparty experiencing losses to meet its obligations to other counterparties. In general, this is implausible. Although a derivatives counterparty might suffer greater losses if it were not able quickly to terminate and close out its positions with a financially-stressed counterparty, this is also true for most other creditors of the firm (those subject to the automatic stay provision). In this sense derivatives counterparties seem no different than other creditors, and we rarely worry about a "chain reaction of insolvencies" when, say, United Airlines defaults on obligations to its vendors.

A "chain reaction of insolvencies" might, however, be worrisome in two situations. One is where a distressed counterparty is a particularly large player in the market and suffers distress as a result of unanticipated economic turmoil that reduces market liquidity. LTCM's distress, for example, was precipitated by Russia's devaluation of the ruble and declaration of a debt moratorium in August 1998. This unexpected event led to a so-called "flight" to liquidity and quality: investors sold-off or avoided high-risk, illiquid financial products and gravitated toward safer, more liquid instruments, sharply increasing yield spreads. LTCM suffered massive losses as yield spreads widened around the world, and found itself on the verge of default in a highly illiquid market. 
Suppose that LTCM had filed a bankruptcy petition and, thanks to the Code's special treatment of derivatives contracts, its counterparties had closed out their contracts and seized collateral. Would this have avoided the risk of a "chain reaction" of insolvencies? No. Indeed, it would have exacerbated the risk. As Edwards (1999) has explained, wholesale liquidation of LTCM's assets would have benefitted few counterparties (prices would have collapsed long before most would have had a chance to liquidate their positions) and could have had serious "knock-on" effects because other counterparties and other banks and financial firms held positions similar to LTCM's. Thus, counterparties could have suffered large losses and been forced to default on their own obligations to other parties, resulting in precisely the same "chain reaction of insolvencies" that Congress sought to avoid by exempting derivatives from the stay. This explains why LTCM's counterparties did not attempt to close out their positions and seize collateral when LTCM entered financial distress. Instead, with encouragement from the Fed, they put an additional \$3.6 billion into LTCM to ensure that it remained solvent so that they would have time to unwind LTCM's derivatives positions in an orderly fashion. For the counterparties, the additional investment in a failing LTCM was obviously viewed as less costly than the expected losses from the wholesale liquidation of LTCM's positions and collateral. As the President's Working Group on Financial Markets (1999) put it, "[t]he self-interest of these firms was to find an alternative resolution that cost less than they could expect to lose in the event of default."

A "chain reaction of insolvencies" may also be a possibility if the distressed counterparty is a particularly large player in the market and counterparties generally failed to employ sound risk management procedures when dealing with the distressed counterparty. Derivatives counterparties, like all other creditors, have strong incentives to manage their credit risks prudently so that losses do not cause them financial distress. The insolvency of a small derivatives counterparty should not result in a "chain reaction" effect because losses will be small, and even the insolvency of a large counterparty like LTCM should not have this effect unless its counterparties behaved imprudently in their dealings with the distressed counterparty (which may have been the case with $\mathrm{LTCM}^{14}$ ). But the better solution to this failure is better risk management by counterparties, rather than amendments to the bankruptcy code exempting derivatives counterparties from its automatic stay provisions. Or, in the case of banks and other regulated financial institutions, which constitute the major derivatives counterparties in OTC derivatives markets, the answer should be either better supervision or a regulatory structure that increases incentives to manage counterparty risk more effectively.

Thus, one view of the potential for LTCM to have caused a systemic crisis is that this crisis was precipitated by the very provisions of the Bankruptcy Code that were designed to assure stability in derivatives markets. Had these provisions not been adopted, it is very likely that there would not have been either an "abrupt and disorderly close-out of LTCM's positions" or an "unwinding [of] LTCM's portfolio in a forced liquidation," and that there would have been no need for the Federal Reserve to intervene to prevent a "seizing up of markets ... [that] could have potentially impaired the economies of many nations, including our own." While counterparties of LTCM may have suffered losses had they been stayed by the Code, it is unlikely that these losses would have been large enough to bring down large banks and securities firms. If they had been stayed by the Code, LTCM's major creditors almost certainly would have opted to facilitate a bankruptcy-supervised creditor "work-out" by putting in more capital and 
reorganizing the ownership structure of LTCM, just as they did under the Federal Reserve arranged work-out. Indeed, as subsequent events showed, it was clearly in the collective interest of LTCM's counterparties and creditors to avoid a "run" on LTCM and the accompanying "firesale" of its assets. Thus, in the absence of the Bankruptcy Code's special treatment of derivatives, Fed intervention may have been unnecessary.

LTCM is not the only large-scale derivatives counterparty to suffer financial distress. Indeed, an even more spectacular failure occurred recently in the form of Enron, which dominated many energy derivatives markets. Partnoy (2002) estimates that Enron made more money trading derivatives during the year 2000 than LTCM made in its entire history, that is, if we believe Enron's 2001 10-K. Unlike LTCM, the federal government did not intervene to help Enron as it entered financial distress (despite lobbying efforts by the firm's bankers ${ }^{15}$ ). Unlike LTCM, Enron did file a Chapter 11 petition. And in stark contrast to the Fed's expectations in LTCM, Enron's bankruptcy did not destabilize either energy derivatives markets or financial markets generally.

This was, to many observers, a surprising outcome (see, e.g., Economist, 2001; Lee, 2001; Financial Times, 2002; Weaver 2004). Indeed, the absence of systemic effects in the wake of a major counterparty's collapse might be seen as evidence that the Code's special treatment of derivatives worked as intended. ISDA (2002a, 2002b) has made precisely this argument: counterparties were free to terminate contracts and seize collateral, thereby minimizing losses. The absence of systemic effects might also suggest, as Kaufman (2003) notes, that the Fed's concerns in LTCM were misplaced: just as in Enron, LTCM's collapse would not have destabilized financial markets.

But Enron's insolvency presented fundamentally different issues than LTCM's. First, it is not true that Enron's failure had little effect on financial markets. Liquidity in energy markets and many specialized markets (such as telecommunications bandwidth trading) collapsed in the wake of the bankruptcy filing. (See ISDA, 2003.) What is true, however, is that this collapse was not as severe as that experenced in the LTCM crises. Also, LTCM's insolvency was driven by mounting losses in its derivatives positions, while Enron's insolvency was driven by sustained and increasing losses in its core non-financial businesses covered up by a massive accounting fraud. If its annual reports offer any guidance, Enron's derivatives trading arm was its only profitable operation (see Partnoy, 2002). Enron indicated, post-petition, that its derivatives trading business accounted for the "lion's share" of its income. ${ }^{16}$ Before and after Enron filed its bankruptcy petition in December 2001, many derivatives counterparties with in-the-money contracts with Enron canceled these contracts and seized collateral. ${ }^{17}$ But many counterparties had out-of-the-money contracts and Enron immediately took steps to collect amounts owed to it ("termination payments"). ${ }^{18}$ These amounts totaled over \$3 billion as of November 2003 (an additional $\$ 2.2$ billion was sought in litigation against counterparties that terminated contracts that, in Enron's view, were disguised loans). ${ }^{19}$ More importantly, Enron's derivatives trading arm continued operating despite the firm's Chapter 11 filing, and the firm moved ${ }^{20}$ quickly to sell the operation to a third-party (ultimately selling it to UBS Warburg ${ }^{21}$ ), thereby minimizing disruption to OTC markets.

For these reasons the collapse of Enron was much different from the collapse of LTCM. Enron's bankruptcy filing did indeed create a "counterparty run" that consumed assets, but the effect of this run was limited by the fact that Enron's trading operations were, it seems, largely 
profitable: some counterparties (with in-the-money positions) were free to seize Enron assets, but another large group of counterparties (with out-of-the-money positions) found themselves liable to Enron. There was no wholesale run on Enron's assets, and no firesale of assets. Although Enron's collapse did create a liquidity vacuum in certain energy derivatives markets, it did not threaten liquidity in overall financial markets-something the Fed feared in the LTCM crisis (see President's Working Group, 1999). Put differently, Enron's collapse did not pose a risk of a systemic meltdown generally. Its insolvency, therefore, neither supports nor undermines ISDA's claim that the Code's special treatment of derivatives minimizes systemic risk nor our claim that the Code can, in some cases, exacerbate systemic risk.

In sum, then, the LTCM episode suggests that the most important risk to financial stability may come from the possibility that derivatives counterparties, exempt from the automatic stay provisions of the bankruptcy code, may "run" on a financially-distressed counterparty (or firm), causing a liquidity shortage that has the potential to spillover to other firms and markets and cause widespread instability in financial markets. In contrast, in the absence of a systemic liquidity shortage, there is no reason to think that derivatives counterparties could not adequately manage their counterparty risks or could not absorb counterparty losses without triggering "a chain reaction of insolvencies."

A Bankruptcy Code exemption for derivatives offers little help in alleviating the potential systemic risk associated with the insolvency of a large derivatives counterparty like LTCM, and may even exacerbate or create a systemic risk. The better approach to mitigating possible systemic risk from a derivatives counterparty failure is to increase incentives for counterparties and creditors to use better risk management procedures, either by enhancing market discipline or by more effective regulatory oversight of regulated financial institution counterparties. But in the event of a market failure, central bank intervention may be the only recourse.

\section{Why give derivatives counterparties special treatment?}

If exempting derivatives from the automatic stay does not make much sense from the perspective of mitigating systemic risk, is the Code's special treatment of derivatives contracts a mistake - the product of effective political pressure on Congress by powerful private interests groups? Not necessarily. In a prior paper (Edwards and Morrison, 2004), we provide an alternative justification for the Code's treatment of derivatives.

In particular, in that paper we argue that the Code's treatment of derivatives is a logical extension of its treatment of cash and cash equivalents. In particular, derivatives contracts are fungible, replaceable assets much like cash; indeed, the Code's definition of "cash collateral" lumps cash and financial securities together. Just as a firm's going-concern surplus will rarely depend on its cash holdings, its surplus will rarely depend on its derivatives contracts or the collateral posted to support those contracts. If one contract is canceled, it can typically be replaced with an identical contract. If a counterparty seizes government securities posted as collateral, these securities are easily replaced. For this reason, common-pool problems and other externalities will rarely (if ever) arise when a counterparty cancels a derivatives contract with an insolvent debtor and seizes collateral.

This view of derivatives contracts and the automatic stay is fairly straightforward in cases involving financial enterprises, such as hedge funds, that become insolvent. The assets of these firms consist entirely of financial contracts. Although much talent and energy may have been 
spent to assemble and manage its contracts, there is little or no going-concern surplus in an insolvent hedge fund. If a fund is insolvent, it is because the value of its portfolio has diminished, at least in the short term. The portfolio may increase in value in the long-term, but this is not a reason to attempt to reorganize the firm. The firm's assets are fungible and its longrun potential is not destroyed when these assets are seized by creditors. Provided the managers can prove that this long-run potential exists (something the managers would have to do even if the firm were reorganized under Chapter 11), outside investors would be willing to pay the firm to reassemble the portfolio.

To be sure, transaction costs will be incurred when the firm reassembles its portfolio, but the small costs of trading in financial markets seem trivial compared to the costs that would be borne by counterparties forced to participate in the bankruptcy process and continue dealing with a firm that may be unable to demonstrate its long-run potential. Indeed, if we are wrong about hedge funds, then broker-dealers too should be treated differently under the Code and the Securities Investor Protection Act, which automatically liquidate broker-dealers. ${ }^{22}$ Finally, while our claim-that the automatic stay should permit derivatives counterparties to cancel contracts and seize collateral-is more complicated when applied to non-financial enterprises, such as manufacturing, energy supply, and telecommunications concerns, we believe it is equally valid.

This argument, obviously, focuses exclusively on the ex post costs and benefits of the Code's treatment of derivatives contracts. From an ex ante perspective, two effects are notable: first, the Code lowers the cost of hedging risk generally, by reducing costs to counterparties from entering contracts with firms that might suffer distress; second, the Code encourages rentseeking behavior by would-be creditors, who have strong incentives to structure loan agreements as derivatives contracts. Interestingly, both effects are potentially costly and therefore cut against an efficiency-based argument in favor of treating derivatives differently.

As to the first effect, the Code undoubtedly reduces the transactions costs of hedging risk. A counterparty is more willing to enter a derivatives contract with a firm (or will enter at a lower price) if it can minimize the costs it may incur if the firm suffers financial distress. The Code reduces these costs by protecting counterparties against "cherry picking” and by increasing the speed with which a counterparty can seize collateral ("cherry picking" occurs when a debtor firm enforces in-the-money contracts and breaches out-of-the-money contracts; counterparties to the latter contracts typically become unsecured creditors and receive pennies on the dollar). Together, these cost-reducing features of the Bankruptcy Code give derivatives counterparties strong incentives to enter contracts with firms even if those firms have a high likelihood of insolvency. Indeed, many economists suggest that the principal benefit of the Code's special treatment of derivatives is that it contributes significantly to the availability of over-the-counter derivatives, increases liquidity in OTC markets, and lowers the cost of hedging risk.

Increased liquidity does not come free, however. The Code reduces the transaction costs of hedging risk by placing derivatives counterparties ahead of other creditors in a bankruptcy proceeding. Counterparties are free to cancel executory contracts and seize collateral while other contractual partners are vulnerable to cherry-picking and other secured creditors must bear some of the costs of the bankruptcy proceedings (including delay in accessing collateral). The Code, then, redistributes wealth from ordinary creditors to derivatives counterparties. Ordinary creditors can respond by increasing the price of credit, which may limit the investment opportunities of some firms, or by seeking to limit (via contract) a borrower's access to OTC 
markets. But these efforts generate transaction costs, which are presumably non-trivial (otherwise the Code's effect on the transaction costs of hedging is implausible).

We therefore question the net social benefit of increasing liquidity in OTC markets via redistributive provisions in the Bankruptcy Code. Enhanced liquidity is undoubtedly a social good, especially when it is the product of technological innovation (such as the growth of organized exchanges). It is less obviously a social good when it is the product of a government subsidy, paid for by other creditors.

The Code's treatment of derivatives contracts may have other negative ex ante effects. Most notably, it encourages would-be creditors to switch to being derivatives counterparties prior to a counterparty's insolvency. For example, an existing creditor might take steps to convert its debt contract into a derivatives contract, or a bank might enter a derivatives contract instead of lending directly to a firm (as in a total return swap). There are, in fact, many ways to offer financing through a derivatives contract rather than an ordinary debt contract, as the ongoing Enron litigation shows. ${ }^{23}$ This type of rent-seeking behavior shifts wealth from general creditors to derivatives counterparties ex post. General creditors may be able to protect themselves ex ante, by charging higher interest rates as compensation for the losses resulting from rent-seeking. Other creditors may be unable to protect themselves, including accident victims (non-consensual creditors). In addition, the Code may unintentionally alter the debt structure of firms towards a greater reliance on derivatives by favoring derivatives counterparties over other creditors. The implications of such shift for firms and debt markets are unclear.

\section{Conclusion}

Our analysis suggests that the Congress's attempt to mitigate systemic risk in OTC derivatives markets by providing special treatment of derivatives under the Bankrutpcy Code is unnecessary and misguided. Indeed, exempting derivatives counterparties from the automatic stay may make matters worse by increasing systemic risk, as it did in the LTCM case. This conclusion, therefore, indirectly calls into question the accepted rationale for providing special treatment of derivatives under the Code, and may even suggest that Congress should repeal the exception for derivatives.

In a prior paper, however, we propose an alternative, efficiency-based, rationale for treating derivatives differently that has nothing to do with fear of systemic risk: that derivatives merit special treatment because they, like cash, are not firm-specific assets. But we recognize that the case for reordering priorities in bankruptcy to favor derivatives counterparties on grounds of economic efficiency is an uneasy one, particularly because it is difficult to evaluate the ex ante inefficiencies of reordering priorities ex post.

Our analysis, however, should give pause to members of Congress and legislators in other countries, who have been lobbied heavily by special interest groups (such as ISDA) to expand the special treatment of derivatives. Lobbyists have argued that such legislation is necessary to prevent a systemic meltdown in OTC derivatives markets should a derivatives counterparty suffer financial distress. Systemic risk may be real, but bankruptcy law has no role to play.

\section{References}

Diamond, Douglas, and Raghuram Rajan, "Liquidity Shortages and Banking Crises," working paper, August. 
Economist, 2001, "Upended: The Imminent Bankruptcy of Enron Could Destabilise Energy and Financial Markets Around the World," November.

Edwards, Franklin R., 1995, "OTC Derivatives Markets and Financial Fragility," Journal of Financial Services Research, December.

Edwards, Franklin R., 1999, "Hedge Funds and the Collapse of Long Term Capital Management," Journal of Economic Perspectives, Spring.

Edwards, Franklin R., and Edward R. Morrison, 2004, "Derivatives and the Bankruptcy Code: Why the Special Treatment?" working paper, July.

Financial Times, 2002, “A Fresh Look at Rules for Energy and Finance," February 19.

International Swaps and Derivatives Association (ISDA), 2002a, "Enron: Corporate Failure, Market Success,"April.

ISDA, 2002b, Prepared Statement of the International Swaps and Derivatives Association, Inc., Before the United States Senate Committee on Agriculture, Nutrition and Forestry, July. April.

ISDA, 2003, "Restoring Confidence in U.S. Energy Trading Markets," white paper,

Kaufman, George G., 2003, "A Proposal for Efficiently Resolving Out-of-the-Money Swap Positions at Large Insolvent Banks," working paper, November.

Michael Krimminger, Insolvency in the Financial Markets: Banks, Hedge Funds, and Other Complications, 18 Banking Policy Report (Jan. 18, 1999).

Lee, Susan, 2001, "The Dismal Science: Enron's Success Story," Wall Street Journal, December 26.

Harold S. Novikoff, Special Bankruptcy Code Protections for Derivative and Other Financial Market Transactions, working paper (2002).

Partnoy, Frank, 2002, "Enron and the Derivatives World," Congressional Testimony, January, reprinted in Nancy B. Rapoport and Bala G. Dharan, eds., 2004, Enron: Corporate Fiascos and Their Implications, New York: Foundation Press.

President's Working Group on Financial Markets, 1999, "Hedge Funds, Leverage, and the Lessons of Long-Term Capital Management,"April.

Roth, Paul N., and Brian Fortune, 2001, "Hedge Fund Regulation in the Aftermath of Long-Term Capital Management," in Iain Cullen and Helen Parry, eds., Hedge Funds: Law and Regulation, London: Sweet and Maxwell.

Weaver, Jacqueline Lange, 2004, "Can Energy Markets Be Trusted? The Effect of the Rise and Fall of Enron on Energy Markets," Houston Business and Tax Law Journal, forthcoming.

United States General Accounting Office (GAO), 1999, "Long-Term Capital Management: Regulators Need to Focus Greater Attention on Systemic Risk," Report to Congressional Requesters, October.

\section{Endnotes}

${ }^{\dagger}$ We thank Barry Adler, Douglas Baird, Michael Johannes, Lynn LoPucki, Hal Novikoff, Robert Rasmussen, and Hayong Yun for helpful comments and conversations.

${ }^{1}$ Greenspan, Alan, 1998, Chairman, Board of Governors of the Federal Reserve System, 
Statement Before the Committee on Banking and Financial Services, U.S. House of Representatives, October 1.

${ }^{2}$ House Rep. No. 97-420, $97^{\text {th }}$ Cong., $2^{\text {nd }}$ Sess., 3 (1982).

311 U.S.C. $\S 362(\mathrm{a})(3)$.

${ }^{4} 11$ U.S.C. $\S 362(\mathrm{~b})(1),(4)$.

${ }^{5} \S$ 362(b)(14), (15), (16).

${ }^{6}$ Bankruptcy Reform Act 1978, as amended, 11 U.S.C. §§ 101-1330, 764 ๑).

${ }^{7}$ House Rep. No. 97-420, $97^{\text {th }}$ Cong., $2^{\text {nd }}$ Sess., 3 (1982).

${ }^{8}$ House Rep. No. 97-420, $97^{\text {th }}$ Cong., $2^{\text {nd }}$ Sess., 3 (1982).

${ }^{9}$ United States, Office of the Comptroller of the Currency 1 (2000).

${ }^{10}$ Hearing of the U.S. House Banking and Financial Services Committee on Hedge Funds, $105^{\text {th }}$ Cong. (Oct. 1, 1998), Statement of William McDonough, President, Federal Reserve Bank of New York.

${ }^{11}$ Id.

${ }^{12} \mathrm{Id}$.

${ }^{13}$ Cayman Islands bankruptcy law was also a concern, because LTCM's sole general partner was a Cayman Islands limited partnership. The Fed analyzed the implications of bankruptcy filings in both the U.S. and abroad. See GAO (1999, Appendix E).

${ }^{14}$ Available evidence suggests that LTCM's counterparties behaved imprudently (by, for example, extending credit at below-market rates and by entering under-collateralized derivatives contracts without verifying the scale or scope of LTCM's trading operations). See GAO (1999, pp. 10-12); President's Working Group (1999, pp. 14-17); Edwards (1999, pp. 204-05).

${ }^{15}$ Senate Committee on Governmental Affairs, Enron's Credit Rating: Enron's Bankers 'Contacts with Moody's and Government Officials. Staff Report (Jan. 3, 2003).

${ }^{16}$ Response and Objection of Exco Resources, Inc., at p. 3, In re Enron Corp., No. 01-16034 (SDNY Bankr. Jan. 8, 2002).

17 See Emergency Motion for an Order Pursuant to Sections 105 and 363 of the Bankruptcy Code and Rule 9019(b) for the Federal Rules of Bankruptcy Procedure for Authority to Negotiate and Enter into Termination or Sale Agreements with Counterparties to Certain "Safe Harbor" Contracts Without Further Court Approval, In re Enron Corp., No. 01-16034 (SDNY Bankr. Dec. 10, 2001).

${ }^{18} \mathrm{Id}$.

${ }^{19}$ Disclosure Statement for Fifth Amended Joint Plan of Affiliated Debtors Pursuant to Chapter 11 of the United States Code 233-34, In re Enron Corp., No. 01-16034 (SDNY Bankr. Jan. 9, 2004).

${ }^{20}$ Motion of Enron Corp. [to Sell Wholesale Trading Business], In re Enron Corp., No. 01-16034 (SDNY Bankr. Dec. 14, 2001).

${ }^{21}$ Order Pursuant to Sections 105, 363, and 365 of the Bankruptcy Code [Approving Sale of Wholesale Trading Arm to UBS Warburg], In re Enron Corp., No. 01-16034 (SDNY Bankr. Jan. 22, 2004).

${ }^{22}$ See $\S \S 109(d), 741$, et seq. and the Securities Investor Protection Act of 1970, 15 
U.S.C. 78111 , et seq.

${ }^{23}$ See, e.g., Enron Corp. v. Citigroup Inc., et al., No. 03-09266 (SDNY Bankr. Sep. 24, 2003); Enron Corp. v. Lehman Brothers Finance, S.A., No. 03-93383 (S.D.N.Y. Bankr. Nov. 21, 2003); Enron Corp. v. Barclays Bank PLC, No. 03-93597 (SDNY Bankr. Dec. 1, 2003);

Memorandum of Law in Support of Defendants the Deutsche Bank Entities' Partial Motion to Dismiss, No. 03-09266 (SDNY Bankr. Feb. 17, 2003) 